\title{
Original Article \\ Application of Hydrological Method for Sustainable Water Management in the Upper-Middle Ciliwung (UMC) River Basin, Indonesia
}

\author{
Imas Komariah, Toru Matsumoto \\ Department of Life and Environment Engineering, the University of Kitakyushu, Kitakyushu, Japan
}

\begin{abstract}
Water resources are under pressure due to population growth, economic development, and changes in land use. This study aims to develop a hydrological method for calculating the water availability and evaluating the water supply demand capacity using the Index of Water Supply-Demand (IWSD), based on a case study of the Upper-Middle Ciliwung river basin in Indonesia. The two hydrological models used in this study were the National Rural Electric Cooperative Association (NRECA) and "FJ. Mock" models. The NRECA model was selected based on a statistical evaluation of correlation coefficients and the volume of errors. Based on the evaluation of business as usual and a reduction in water availability scenarios, the IWSD shows a value $>0$, which means that the river can supply the necessary water for the economy, society, and environment. For other scenarios, with an increase in population growth and mix scenario, the $I W S D$ shows values $<0$, which means that the river cannot supply water for the users. The applications of the hydrological methods were developed in order to understand and seek solutions for decision makers in sustainable water resource management.
\end{abstract}

Keywords: hydrological methods, FJ. Mock, National Rural Electric Cooperative Association, water supply demand

\section{INTRODUCTION}

The current and future challenges of water resources management vary widely because of the population growth, changes in land use, intensive socio-economic development, and warming climate [1]. Sustainable water resource management has become a very important issue because of the lack of good quality water resources due to environmental damage caused by the pressure of human activities.

This affects the balance between the supply and demand for water resources. The evaluation of the water supply capacity and water demand in a river basin can contribute to decision-making and strategy of sustainable water resources management. The evaluation of the water supply demand capacity aims to determine the balance between water supply and demand in a basin, in a certain period, using the Index of Water-Supply Demand (IWSD) method.

The water supply is calculated by a hydrological method whereas the water requirement is calculated based on each sector's water needs and environmental water demand. There are several common hydrological models: Soil and Water Assessment Tool (SWAT) [2], Genie Rural four parameters Journal (GR4J) [3], Tank model [4], Rainrun [4], National Rural Electric Cooperative Association (NRECA) [5], and FJ. Mock [6,7]. The SWAT model uses parameters such as land use change, global change, and land conservation techniques [2]. The GR4J model uses daily input data of rainfall and evapotranspiration, the maximum capacity of the production store, the water exchange coefficient, the maximum capacity of the routing store, and the time base of a unit hydrograph [3]. The Tank model describes the several combination tanks for each soil layer in the catchment area [4]. The Rainrun model takes into account the average weighted runaway components of the forest and non-forest catchment fraction [4]. The NRECA uses an index of the soil moisture storagecapacity, the rate of discharge from groundwater storage to a 


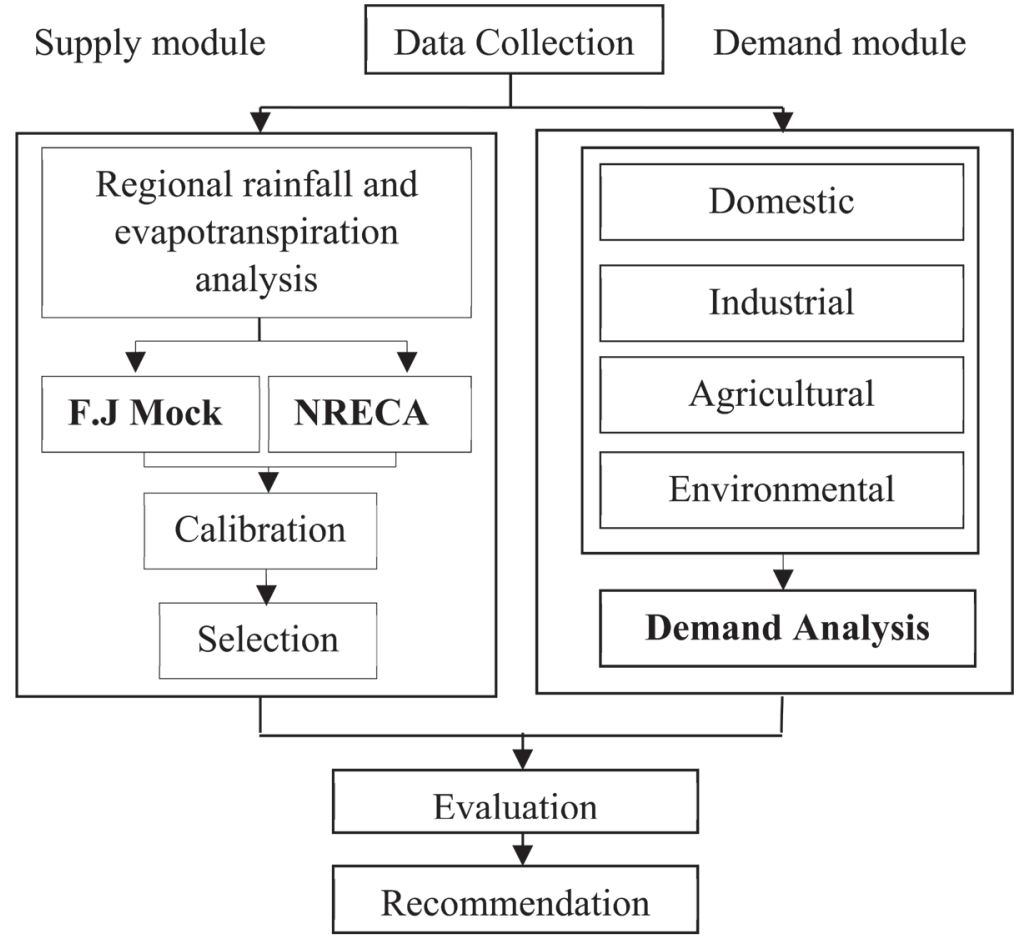

Fig. 1 Structure of the method.

stream, daily rainfall data, and potential evapotranspiration data [5]. The FJ. Mock model uses daily rainfall data, evapotranspiration, and hydrologic watershed characteristics. This model provides a good alternative tool for rapid watershed assessment using hydrological parameters as part of monitoring and evaluation, particularly in the regions with limited hydrological data [6,7]. The selection of a hydrological model is based on the watershed characteristics, data availability, and expected output.

In this study, two models were used: the FJ. Mock and NRECA. The model accuracy is evaluated by calibration and validation between the simulation results and observation data using two indicators: the $r$ and the Volume of Errors $(V E)$.

The objectives of this study are:

(1) to select a hydrological model in order to estimate the water supply in a river basin based on limited data and an accuracy model.

(2) to evaluate and analyze the water supply demand capacity with several scenarios for contributing to sustainable water resources management.

The methods were applied to the Upper-Middle Ciliwung (UMC) river basin in Indonesia with a coverage area of $264.35 \mathrm{~km}^{2}$ [8]. This basin has a high population growth. The population served by piped water is still low. Known issues in this river basin are the degradation of the water's quantity and quality and the high rate of land use change $[2,8]$.

River restoration activities are dredging sediment and garbage from the river and utilization of domestic and industrial wastewater treatment technologies will increase the quantity and quality of the river water. The application of the hydrological method to evaluate the water supply demand capacity is useful for consideration in the framework of future water resource development. By using various scenarios of water supply and demand, it can be found whether the river can supply water for economic, social, and environmental needs within a certain period.

\section{CONCEPT AND METHOD}

\section{Concept of application of hydrological method for sustainable water resources management in the riv- er basin}

The method is composed of the supply and demand modules. The supply module is based on a regional rainfall, evapotranspiration, and hydrological model. The demand module based on water needs for each sector (domestic, industrial, and agricultural) and the environmental water demand. The structure of the method is shown in Fig. 1. The evaluation of the water supply and demand capacity 
took place with scenarios of increasing water demand, due to population growth and economic development, and water supply reduction due to climate change. IWSD's calculation results will recommend solutions towards the sustainability of water resources management. A value $>0$, means that the river can supply the water for the economy, society, and environment while a value $<0$, means that it is necessary to find a solution for a more sustainable water resources management.

\section{Methodology}

The methodology used in this study is comprised of the following:

1) Establishment of NRECA and FJ. Mock hydrological models with an analysis of rainfall and climate data into regional rainfall and evapotranspiration categories

2) Calibration and validation of the models

3) Method selection by comparing the method deviation values

4) Demand model analysis

5) Comparison between water supply and demand for several scenarios with the IWSD formula

6) Making recommendations regarding the water supply and demand in the catchment area.

The scenario used in this study was organized by consideration of parameters in the river's region: population growth, economic growth, land use change, and climate change. Based on population census from 1998 until 2008, the population growth rate in UMC river basin was $2.74 \%$, the higher population growth rate from 2004 until 2006 was around $5.28 \%$ until 6.52\% [3]. The economic growth rate from 1960 until 2010 showed varieties which tend to be stable between $5 \%$ and $6 \%$ a year so moderate economic growth scenario can be used with 5-6\% economic growth rate [8]. Land use change in the UMC river basin is an average of 7.45\% [8]. Climate change prepares for the worst condition (increasing and/or decreasing of rainfall $\pm 0.3 \mathrm{~mm} /$ day) [8].

In this study, the following scenarios were developed:

1. Reference or business as usual (BAU)

2. Scenario one: $5 \%$ population growth rate

3. Scenario two: $5 \%$ reduction of water availability

4. Mix scenario

The equation of the hydrological balance in the catchment area is as follows:

$$
\text { In }=\text { Out } \pm \Delta S
$$

In: inflow of water to the hydrological unit.

Out: outflow of the hydrological unit.

$\Delta S$ : change in storage within the selected hydrological unit (e.g. catchment).

\section{Regional rainfall and evapotranspiration analysis}

The regional rainfall is transformed from monthly rainfall data. An algebraic method was used because the catchment area is between 250 and 50,000 ha. The formula of the algebraic method is as follows:

$$
R_{H}=\frac{H_{1}+\ldots+H_{n}}{n}
$$

$R_{H}$ : average regional rainfall ( $\left.\mathrm{mm}\right)$,

$H$ : monthly rainfall data from gauge station $1,2, \ldots n$,

$N$ : number of gauge stations.

Evapotranspiration is the total volume of evaporation from the surface of the soil, ground surfaces, wetlands, natural water bodies, and transpiration of plants $[9,10]$. The Penman's equation is:

$$
\begin{aligned}
& E T p=F_{1} \cdot R(1-r)-F_{2}(0.1+0.9 S)+F_{3}(k+0.01 w) \\
& F_{1}=A \frac{0.18+0.55 S}{(A+0.27)} \\
& F_{2}=A B \frac{0.56-0.092 e d^{0.5}}{(A+0.27)} \\
& F_{3}=\frac{(0.27)(0.35)(e a-e d)}{(A+0.27)}
\end{aligned}
$$

$A$ : slope of the vapor pressure curve $\left(\mathrm{Hg} /{ }^{\circ} \mathrm{F}\right)$,

$B$ : black body radiation based on the value of temperature $\left(\mathrm{Hg} /{ }^{\circ} \mathrm{F}\right)$,

ea: saturation vapor pressure for the measured air temperature ( $\mathrm{mm} \mathrm{Hg}$ ),

$e d$ : actual vapor pressure of the $\operatorname{air}(\mathrm{mm} \mathrm{Hg})=e a \times$ relative humidity (\%),

$S$ : average percentage of monthly of sun-shine,

$R$ : solar radiation $(\mathrm{mm} / \mathrm{d})$,

$r$ : reflection coefficient,

$k$ : evaporation surface roughness coefficient $=(1,0)$, and $w$ : wind velocity (mile/d).

The actual evapotranspiration is described as follows:

$$
\Delta E=E T p \times\left(\frac{m}{20}\right) \times(18-h)
$$




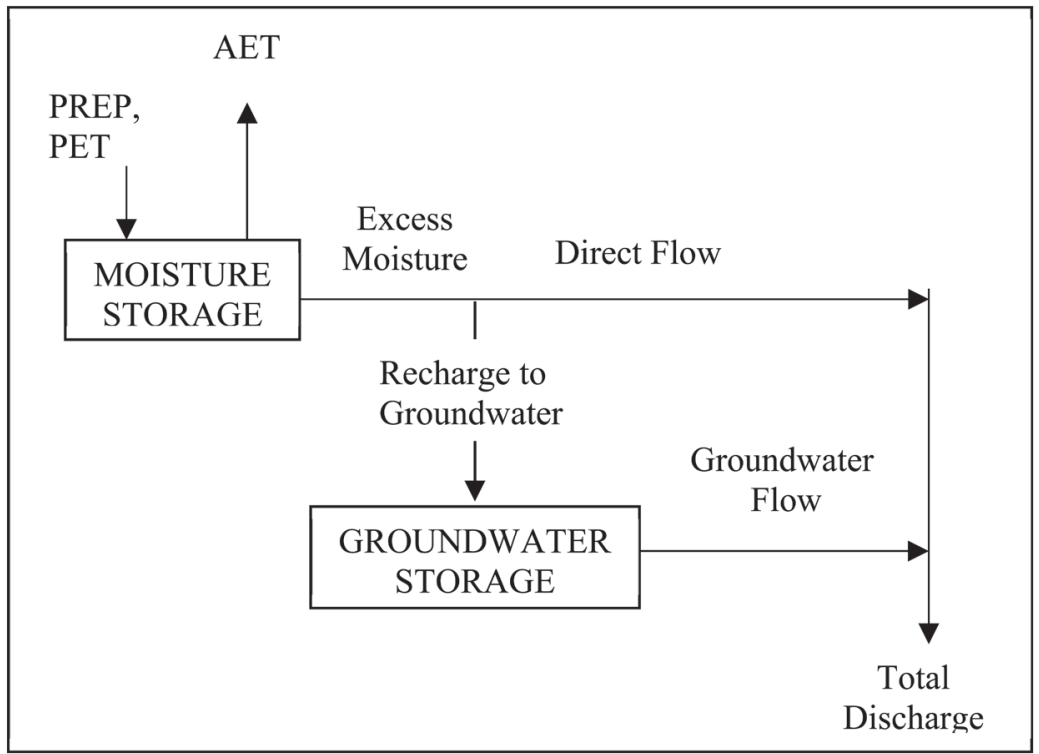

Fig. 2 Schematic of monthly runoff calculations from rainfall and potential evapotranspiration data [5].

$$
E T a=E T p-\Delta E
$$

$E T_{p}$ : potential evapotranspiration (mm/day),

$\triangle E$ : difference between potential evapotranspiration and

limited evapotranspiration,

ETp: potential evapotranspiration,

ETa: actual evapotranspiration,

$h$ : number of rainy days in a month, and

$m$ : percentage of land covered vegetation ( $m=0 \%$ dense forest, $m=(10-40 \%)$ eroded land, and $m=(30-50 \%)$ agricultural land).

\section{Description of NRECA model}

The NRECA model was developed by Norman H. Crawford (USA) in 1985. This model is a simplification of the Standard Watershed Model IV (SWM).

NRECA model is developed in the USA which is a subtropical country while Indonesia has a tropical climate so the rainfall conditions are different. Besides, the kind of soil and land covering vegetation are also different.

NRECA model has five parameters to count the water debit in a river basin where each parameter has its own certain value regarding the rainfall condition, kind of soil, and the land covering vegetation. To count the water discharge, trials and errors are done towards the value of the parameter mentioned so the water discharge result is counted with the tolerance limit at $\leq 10 \%$ if validated towards the measure- ment result. Those five parameters of the NRECA model are:

- NOM or Nominal: an index of the soil moisture storage capacity in the watershed, with values $\mathrm{NOM}=100+\mathrm{C} \times$ average annual rainfall, where $C$ is approximately 0.2 in watersheds with precipitation throughout the year and 0.25 in watersheds with seasonal rainfall;

- GWF: an index to the rate of discharge from the groundwater storage to the stream, with values ranging from 0.2 -0.9 ;

- PSUB: the fraction of runoff that moves out of the watershed as base flow or groundwater flow, with values ranging from $0.3-0.8$;

- SMSSTOR: the initial moisture storage, with values ranging from $500-760$;

- GWSTOR: the initial groundwater storage, with values ranging from $200-330$.

A diagram of the calculations is shown in Fig. 2. The water balance equation is:

$$
\begin{aligned}
\text { run off } & =\text { precipitation }- \text { actual evapotranspiration } \\
& + \text { storage }
\end{aligned}
$$

The total river discharge was analyzed with the following formula [5,11]:

$$
Q=(\text { direct flow }+ \text { groundwater flow }) \times A
$$

$A$ : number area $\left(\mathrm{km}^{2}\right)$,

direct flow: excess moist - recharge to groundwater, excess moist: excess moist ratio $\times$ water balance, water balance: precipitation $-A E T$,

AET: $P E T \times(A E T / P E T)$ ratio from Fig. 3, 


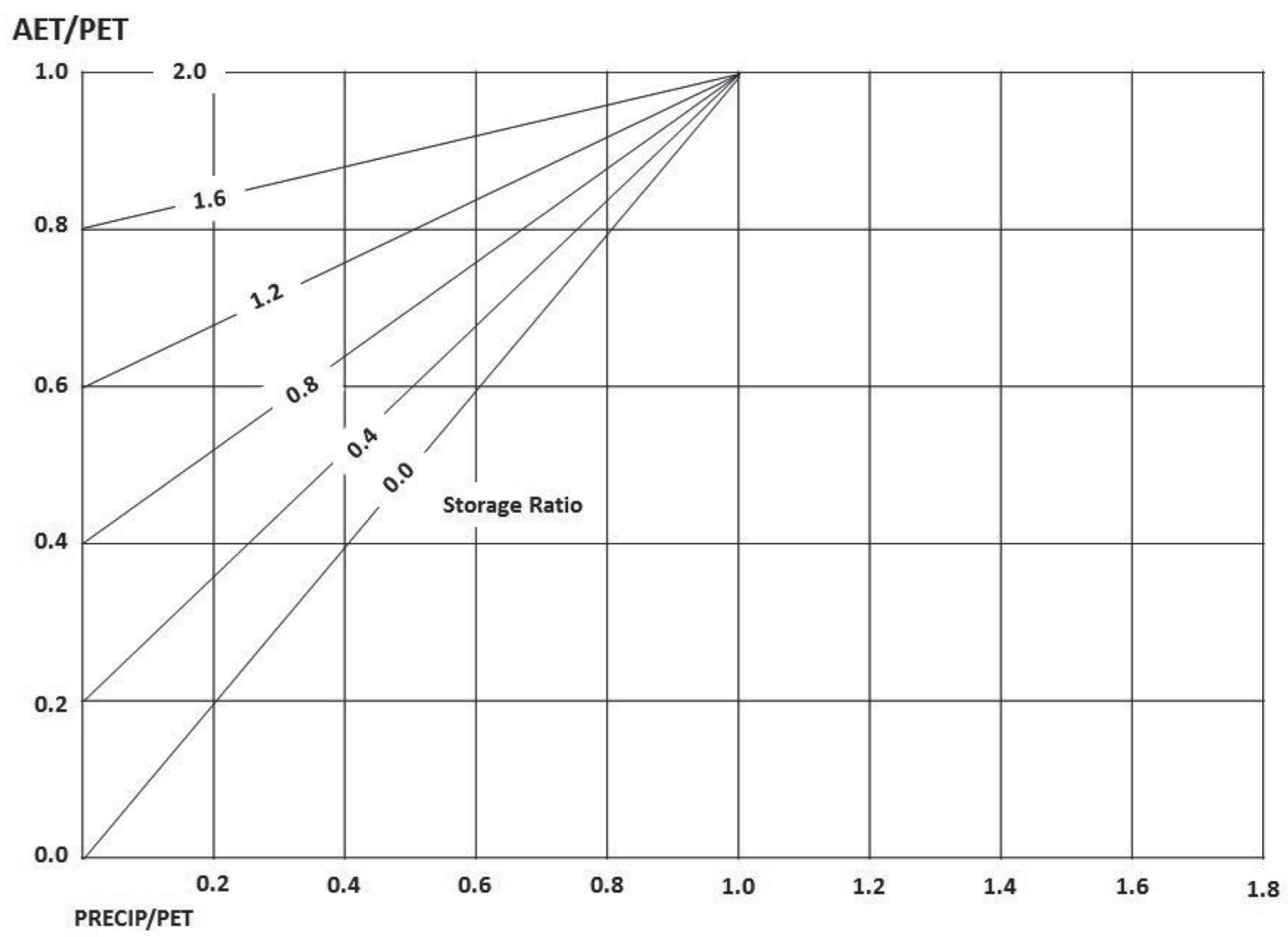

Fig. $3 A E T / P E T$ ratio as a function of PRECIPITATION/PET and soil moisture ratio.

The excess moist ratio $=0$ if the water balance is negative. If the water balance is positive, the moist ratio is obtained by the soil moisture storage ratio, Fig. 4.

storage ratio: moisture storage/Nominal,

NOM: given by $100+0.2 \times$ average annual rainfall,

Nominal: an index of the soil moisture storage capacity in the watershed,

recharge to groundwater: given by PSUB $\times$ excess moist,

Groundwater flow: given by GWF $\times$ (recharge to groundwater + BEGIN STOR GW),

PET: potential evapotranspiration,

\section{Description of FJ. Mock model}

A flowchart of the calculations is shown in Fig. 5.

\section{Method performance evaluation}

The model accuracy was evaluated by calibration and validation using the $r$ and $V E$ indicators. The formula can be seen in equations (11) and (12). The model is rated as having a high associate degree if the value of $r$ is $0.7<r$ $<1$. Calibration refers to the adjustment of model parameters to reproduce observations within acceptable levels of agreement. A validation test was conducted by applying the calibrated model to a second period of data not used in the calibration [12].

$$
\begin{aligned}
& r=\frac{n \sum \mathrm{X}_{i} \mathrm{Y}_{i}-\left(\sum \mathrm{X}_{i}\right)\left(\sum \mathrm{Y}_{i}\right)}{\sqrt{\left\{n \sum \mathrm{X}_{i}^{2}-\left(\sum \mathrm{X}_{i}\right)^{2}\right\}\left\{n \sum \mathrm{Y}_{i}^{2}-\left(\sum \mathrm{Y}_{i}\right)^{2}\right\}}} \\
& V E=\frac{\sum_{i}^{n} X_{i}-\sum_{i}^{n} Y_{i}}{\sum_{i}^{n} X_{i}} \times 100 \%
\end{aligned}
$$

$r$ : correlation coefficient,

$V E$ : volume error,

$x_{i}$ : simulated daily discharge $\left(\mathrm{m}^{3} / \mathrm{sec}\right)$,

$y_{i}$ : observed daily discharge $\left(\mathrm{m}^{3} / \mathrm{sec}\right)$,

$n$ : total step calibration.

\section{Water demand model}

The water demand model consists of the domestic, industrial, agricultural, and environmental water demand [13]. The formula for calculating water requirements is as follows: 
Excess Moisture Ratio

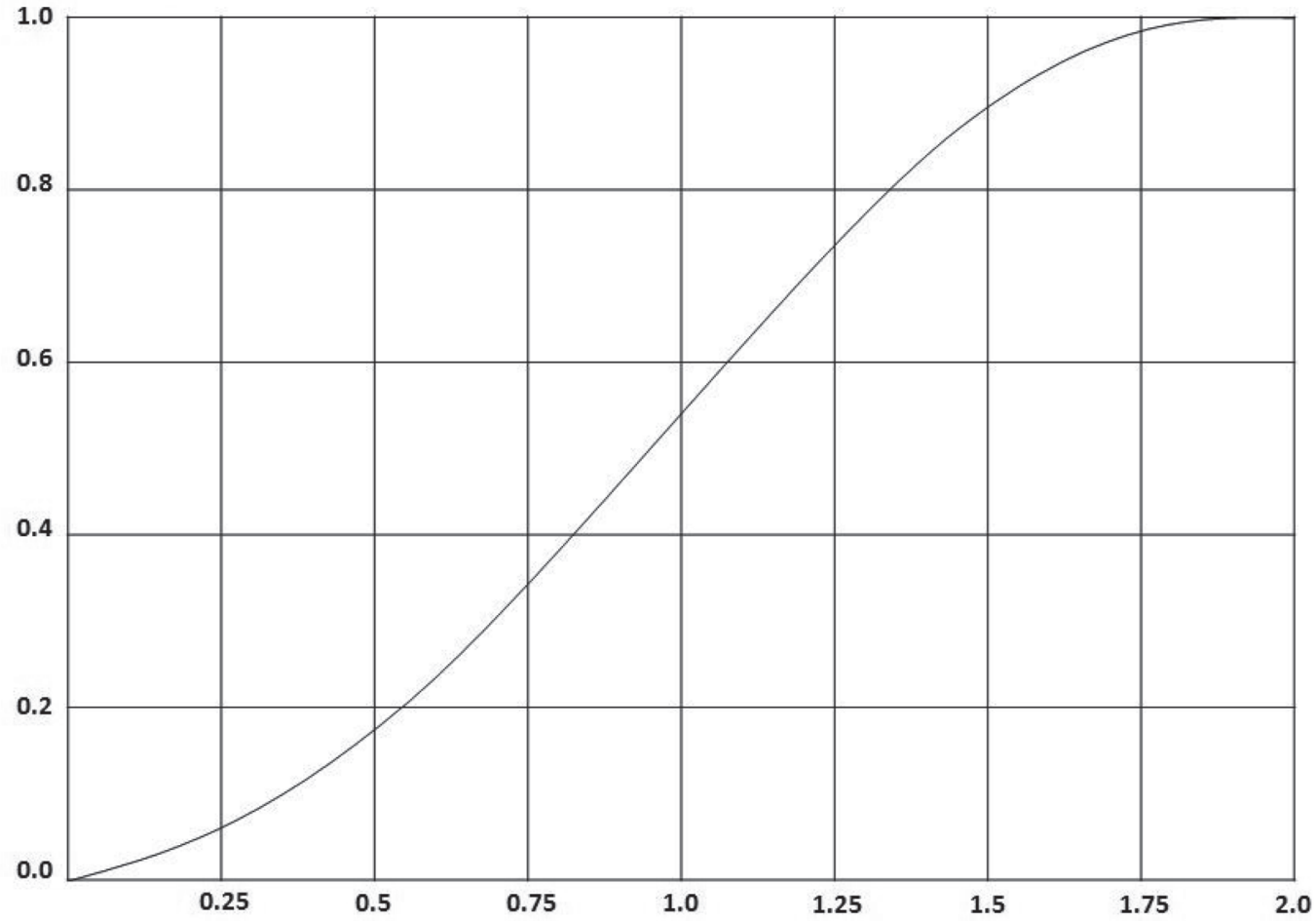

Soil Moisture Storage Ratio

Fig. 4 Soil moisture storage ratio.

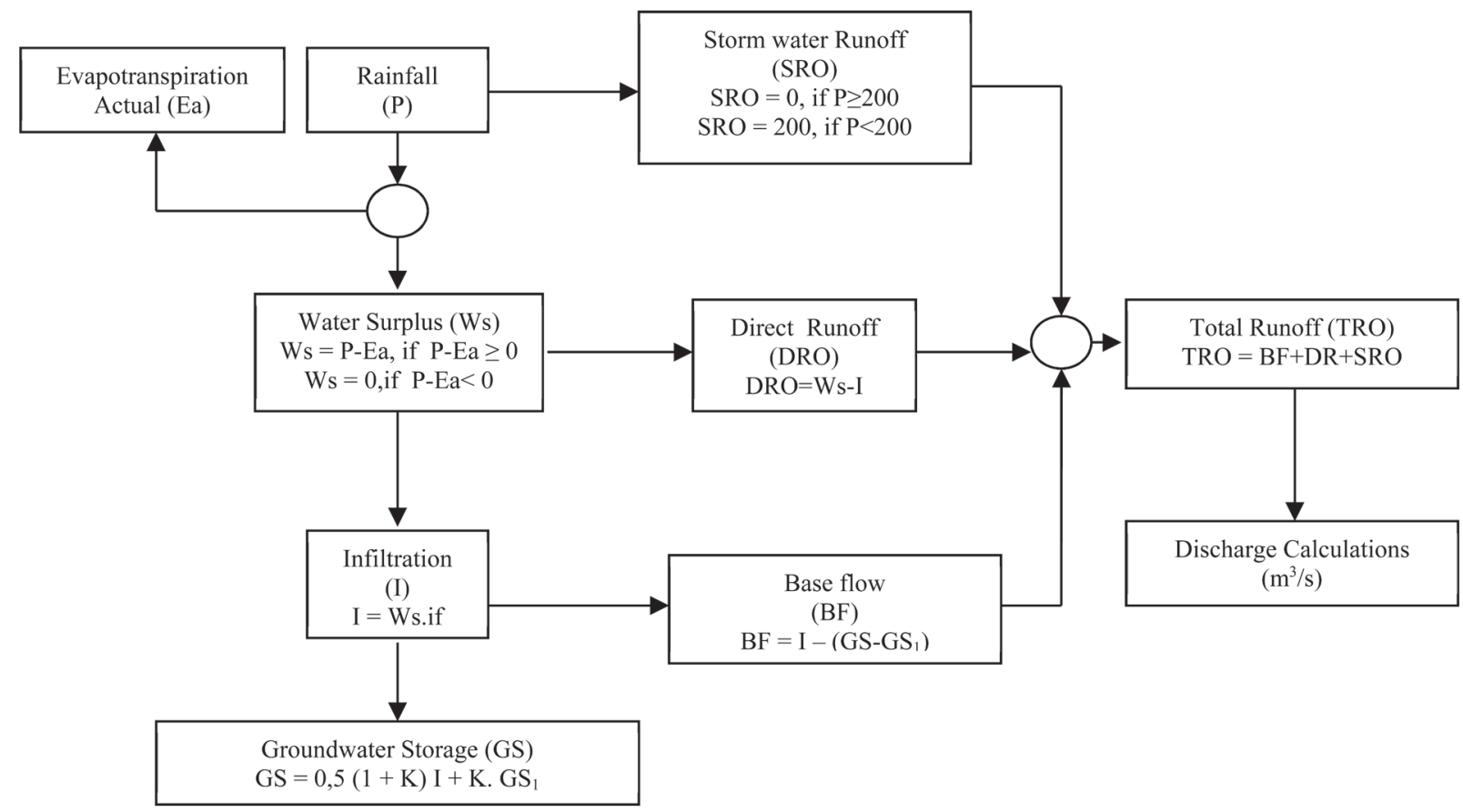

Fig. 5 Flowchart of Mock calculation [13]. 
Table 1 Standard water demand for unit water demand.

\begin{tabular}{lll}
\hline \hline No. & Unit water demand & Standard \\
\hline 1 & Domestic & $160 \mathrm{~L} /$ people/day \\
2 & Big Industrial process & $65000 \mathrm{~L} /$ day/unit \\
3 & Smallindustrial process & $1000 \mathrm{~L} /$ day/unit \\
4 & Industrial worker & $60 \mathrm{~L} /$ people/day \\
5 & Agriculture & $1.2 \mathrm{~L} / \mathrm{ha} / \mathrm{sec}$ \\
6 & Environmental & $300 \mathrm{~L} /$ people/day \\
\hline
\end{tabular}

water requirement $=$ water demand unit $\times$ standard $(13)$

The standard can be seen in Table 1 [14]. Domestic water requirements are calculated based on the projected population according to the geometric method:

$$
P n=P_{O}(1+r)^{n}
$$

$P n:$ projected population in the future,

Po: initial population,

$r$ : annual population growth rate, and

$n$ : time or period.

\section{Dependable flow}

The dependable flow is the amount of available discharge to meet water needs, taking into account the risk of failure (Table 2). The level of reliability of discharge may occur under probability of occurrence, following the Weibull formula [15]:

$$
P \%=\frac{m_{2}}{\left(n_{2}+1\right)} \times 100 \%
$$

$P \%$ : probability percentage (\%),

$m_{2}:$ serial number of the data, and

$n_{2}$ : amount of data.

\section{Water supply and demand capacity evaluation method}

The formula of water supply and demand capacity evaluation is as follows:

$$
I W S D=1-\text { water demand/water supply }
$$

If $I W S D<0$, the volume of usable water is not sufficient to support the economy, society, and environment [16].

\section{DESCRIPTION OF FIELD AND DATA}

The UMC river basin is located between $106^{\circ} 50^{\prime} 20^{\prime \prime}$ to $106^{\circ} 50^{\prime} 50^{\prime \prime}$ East Longitude and $6^{\circ} 22^{\prime} 30^{\prime \prime}$ to $06^{\circ} 28^{\prime} 35^{\prime \prime}$ South
Table 2 Dependable flow for water planning.

\begin{tabular}{ll}
\hline \hline Planning water demand & Probability \\
\hline Drinking water & P $90 \%$ \\
Hydropower & P $(85-90) \%$ \\
Irrigation & P $(70-85) \%$ \\
\hline
\end{tabular}

Latitude, comprising a total area of $264.35 \mathrm{~km}^{2}$ (Fig. 6). Two main urban centers (the cities of Bogor and Depok) and Bogor regency are within the basin with a total permanent population of 3.79 million people (2014 census). The main river in this basin is Ciliwung with a length of $119 \mathrm{~km}$, an average rainfall of 1586 to $2486 \mathrm{~mm}$ /year, a maximum temperature of $30^{\circ} \mathrm{C}$, and a humidity of between $65 \%$ and $70 \%$ [17].

The data collected for this study can be classified into five different categories, i.e., hydrology data (daily rainfall data and discharge river actual data), land use and soil characteristics, meteorological data (precipitation, relative humidity, sunshine hours, average temperature, and wind speed), population data, and water usage data (irrigation and industry). The data were collected from the Statistical District Data and Ciliwung-Cisadane River Basin Agency. Daily rainfall data were used from Gandog, Cibinong, UI-Depok, and Gunung Mas stations for the years between 2008 and 2012. The observed data were taken from Katulampa weir.

\section{RESULTS AND DISCUSSION}

\section{Regional rainfall and evapotranspiration}

The hydrology method built for this study is a rainfallrunoff model that uses daily rainfall and climate data. The result of the average rainfall regional analysis, using algebraic methods, shows the highest rainfall value of $457.9 \mathrm{~mm}$ and the lowest of $21.09 \mathrm{~mm}$. The average monthly rainfall ranges from $91.36 \mathrm{~mm}$ to $369.34 \mathrm{~mm}$. The results can be seen in Figs. 7 and 8. The evapotranspiration results obtained by the Penman's method can be seen in Fig. 9.

\section{Model calibration and validation}

The model calibration is a process of obtaining the best fit between the observed and simulated results by adjusting the input parameter values, whereas model validation is the process of comparing a set of observed data with the simulation results without adjusting any input parameter values [18]. A 12-month test run from January to December 2011 was carried out in order to calibrate the model parameters. The model validation was carried out from January to December 2012 . 

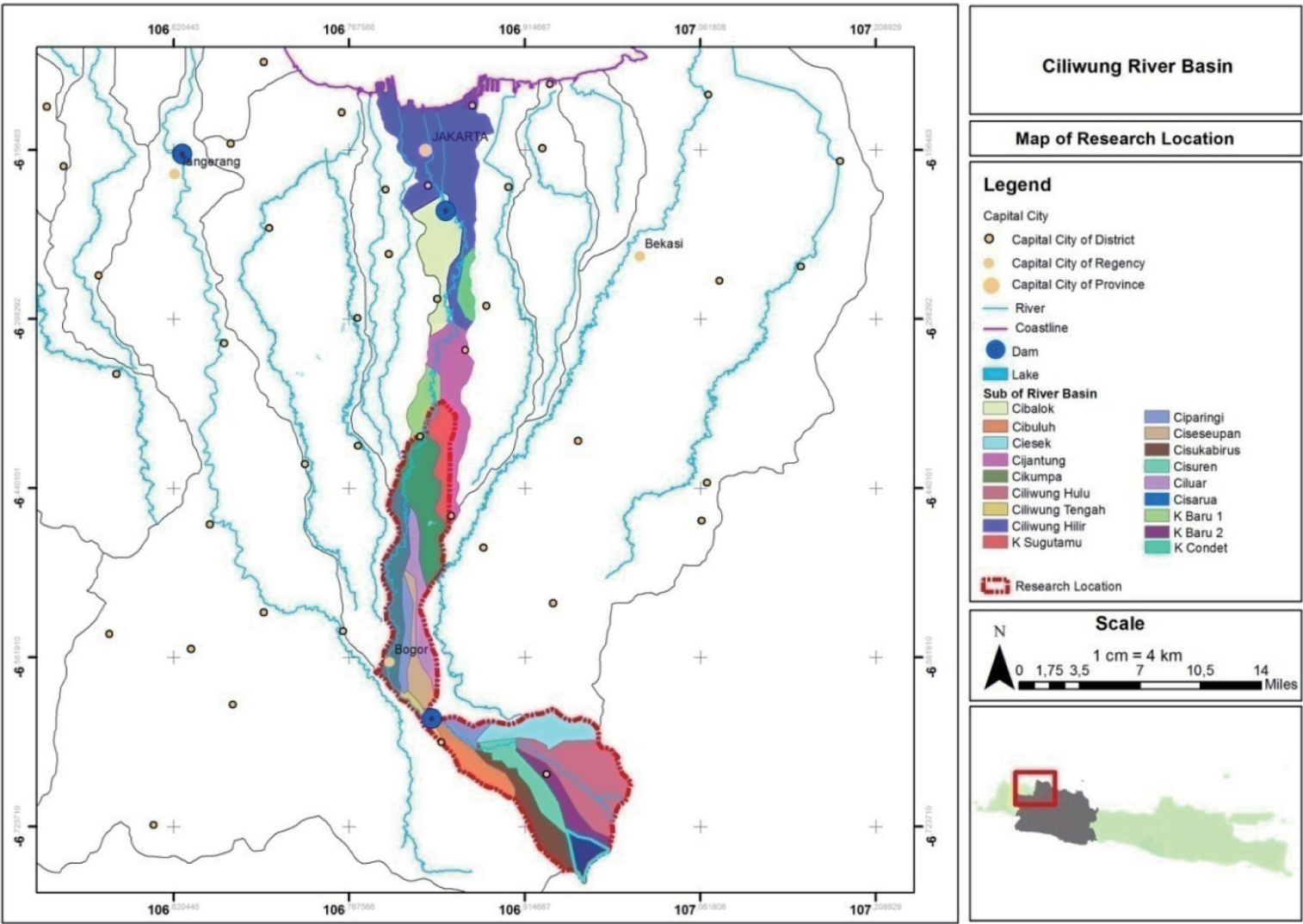

Fig. 6 Research location.

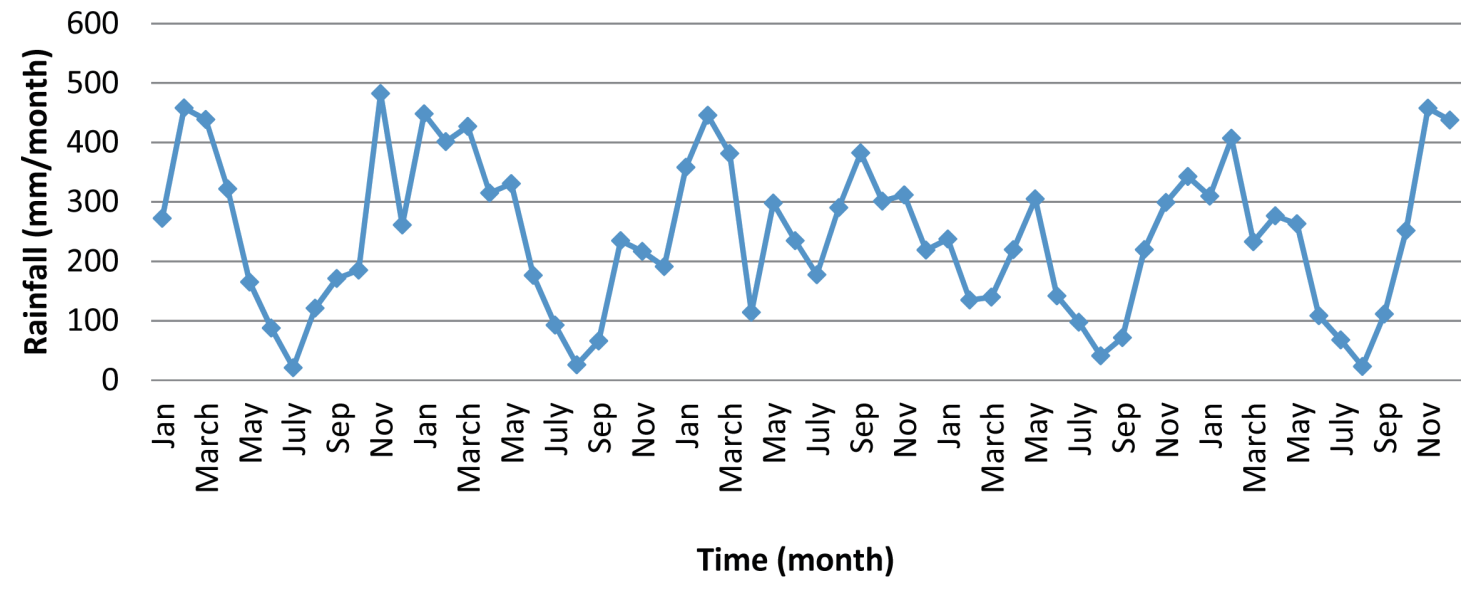

Fig. 7 Monthly regional rainfall from 2008 to 2012.

Table 3 shows the parameters and values of the calibration results for the NRECA model. The NRECA model performance for the calibration and validation periods can be seen in Table 4. Based on the calibration and validation values obtained, model NRECA is chosen to count the water discharge in $\mathrm{UMC}$ river basin with the most optimal parameters used:
NOM 400 mm, PSUB $0.5 \mathrm{~mm}$, GWF $0.27 \mathrm{~mm}$, SMSSTOR $700 \mathrm{~mm}$, and GWSTOR $330 \mathrm{~mm}$.

Table 5 shows the parameters and values of the calibration results for the FJ. Mock model.

The FJ. Mock model performance for the calibration and validation periods can be seen in Table 6 . 


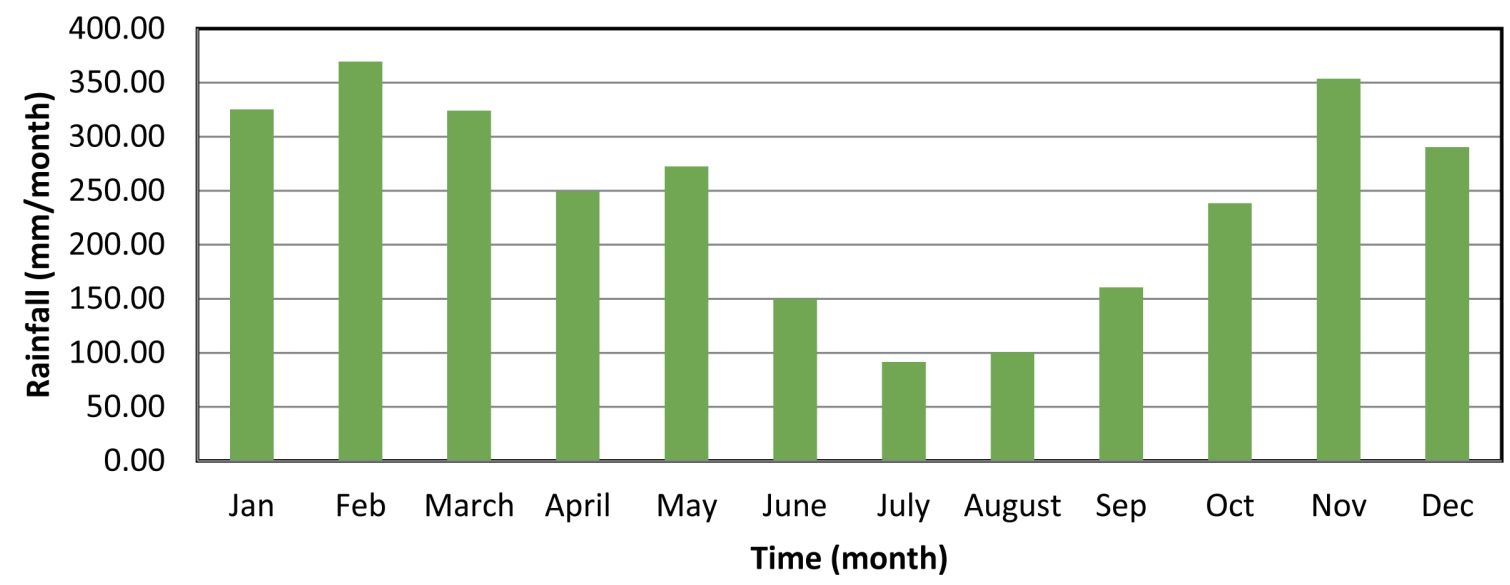

Fig. 8 Monthly average regional rainfall in the UMC river basin.

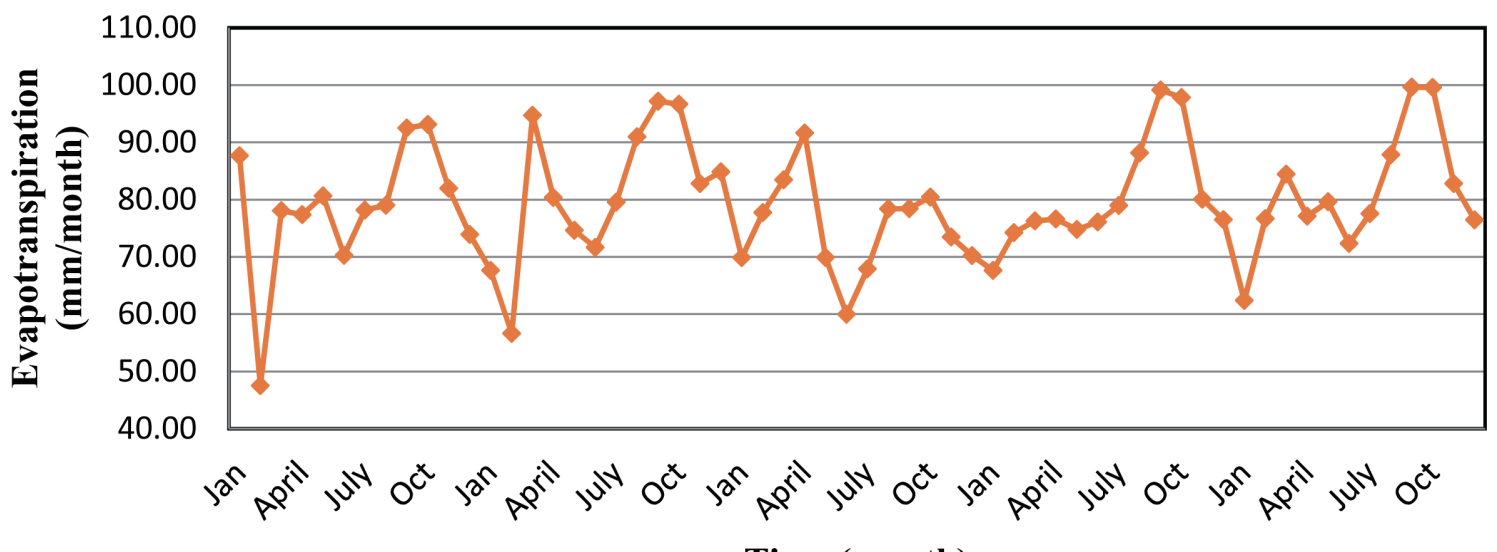

Time (month)

Fig. 9 Monthly evapotranspiration using Penman's method from 2008 to 2012.

The hydrological method used to estimate the water availability in the UMC river basin was the NRECA model because the calibrated values of $r$ and $V E$ were 0.90 and 0.25 , respectively, while the values obtained from the FJ. Mock model were 0.81 and 0.24 , respectively. Figures $\mathbf{1 0}$ and 11 show a comparison between the simulated and observed monthly discharges and Fig. 12 shows the comparison graph between the NRECA and FJ. Mock.

\section{Application of the hydrologic method for estimating water availability in the $\mathrm{UMC}$ river basin}

Water availability at the UMC river basin was estimated using the NRECA hydrology model. The model input data is the catchment area of $264.4 \mathrm{~km}^{2}$, the rainfall and evapotranspiration of the calculation results (Figs. 7 to 9), and the optimal model parameters of the calibration process: NOM 400, PSUB 0.5, GWF 0.27, SMSTOR 700, and GWSTOR
330.

The results of water availability and dependable discharge calculations can be seen in Table 7 .

Based on the calculations of water availability in Table $\mathbf{8}$, the calculated dependable flow for each water planning is $90 \%$ probability for drinking water, $85 \%$ probability for hydropower, and 80\% probability for irrigation, Fig. 13.

\section{Water demand in the UMC river basin}

The total water requirement in the UMC river basin was calculated based on the water users in Table 8 [17,19-21].

Future water requirements are estimated by projections according to the planning time. Based on the existing data on the population number, from 2005 to 2014, Table 9, the population growth is $3.34 \%$.

The value of $r$ is calculated as follows: $r=(P n / P o)^{(1 / n)}-1$ 
Table 3 Final calibrated flow parameter values for NRECA model.

\begin{tabular}{|c|c|c|c|c|}
\hline Discharge parameters & Units & Symbol & Low and upper bounds & Fitted values \\
\hline Initial nominal & $\mathrm{mm}$ & Nom & $200-400$ & 400 \\
\hline $\begin{array}{l}\text { The fraction of runoff that moves } \\
\text { out of the watershed as base flow or } \\
\text { groundwater flow }\end{array}$ & $\mathrm{mm}$ & PSUB & $0.3-0.8$ & 0.50 \\
\hline $\begin{array}{l}\text { An index to the rate of discharge } \\
\text { from the groundwater storage to the } \\
\text { stream }\end{array}$ & $\mathrm{mm}$ & GWF & $0.2-0.9$ & 0.27 \\
\hline Initial moisture storage & $\mathrm{mm}$ & SMSSTOR & $500-760$ & 700 \\
\hline Initial groundwater storage & $\mathrm{mm}$ & GWSTOR & $200-330$ & 330 \\
\hline
\end{tabular}

Table 4 Summary of model performance for calibration and validation periods for NRECA model.

\begin{tabular}{lcccc}
\hline \hline Period & \multicolumn{2}{c}{ Mean annual water yield $(\mathrm{mm})$} & \multicolumn{2}{c}{ Monthly method efficiency } \\
\cline { 2 - 5 } & Observed & Simulated & $r$ & $V E$ \\
\hline Calibration & 157.58 & 118.2 & 0.90 & 0.25 \\
Validation & 172.83 & 166.2 & 0.97 & 0.03 \\
\hline
\end{tabular}

Table 5 Final calibrated flow parameter values for FJ. Mock model.

\begin{tabular}{lcccc}
\hline \hline Discharge parameters & Units & Symbol & $\begin{array}{c}\text { Low and upper } \\
\text { bounds }\end{array}$ & Fitted values \\
\hline Reflection coefficient & - & $r$ & 0.4 & 0.4 \\
Exposed surface & $\mathrm{mm}$ & $\mathrm{m}$ & $(30-50) \%$ & 40 \\
Coefficient of infiltration & $\mathrm{mm}$ & if & $0.3-0.35$ & 0.35 \\
Groundwater recession constant & - & $\mathrm{K}$ & $0.5-0.95$ & 0.8 \\
Percentage of rainfall into runoff & $\mathrm{mm}$ & $\mathrm{Pf}$ & $0.05-0.1$ & 0.1 \\
\hline
\end{tabular}

Table 6 Summary of model performance for calibration and validation periods for FJ. Mock model.

\begin{tabular}{lcccc}
\hline \hline Period & \multicolumn{2}{c}{ Mean annual water yield $(\mathrm{mm})$} & \multicolumn{2}{c}{ Monthly method efficiency } \\
\cline { 2 - 5 } & Observed & Simulated & $r$ & $V E$ \\
\hline Calibration & 157.58 & 119.4 & 0.81 & 0.24 \\
Validation & 172.83 & 178.22 & 0.95 & 0.03 \\
\hline
\end{tabular}

$$
=(3.79 / 2.82)^{(1 / 9)}-1
$$$$
=0.0334 \text { or } 3.34 \%
$$

The projected population for the next 50 years based on BAU with a population growth rate of $3.34 \%$, and scenario 1 with a population growth rate of $5 \%$, can be seen in Table $\mathbf{1 0}$.

The results of the calculations for the water requirements for each scenario can be seen in Tables 11 and 12. Volume of WS and WD for evaluation of two scenarios can be seen in Table 13.

\section{Evaluation of water supply demand capacity of the UMC river basin}

The development and the application of hydrological methods have been a cornerstone of hydrological research for many decades. The purpose of the development of these methods is to improve the understanding of hydrological processes involved in the rainfall and runoff transformations and to provide practical solutions for water resources management problems [22].

In this study, a hydrological method is used to evaluate whether the availability of water in the river basin can still meet the needs of its users. The evaluation was done with two scenarios. The first scenario assumed an economic growth of $5 \%$ and a population growth of $5 \%$. The second scenario assumed a $5 \%$ reduction in water availability due to changes in the forest area, which decreases every year by an average of $7.45 \%$ and the existence of global climate change.

Based on the IWSD formula, an evaluation of the water 


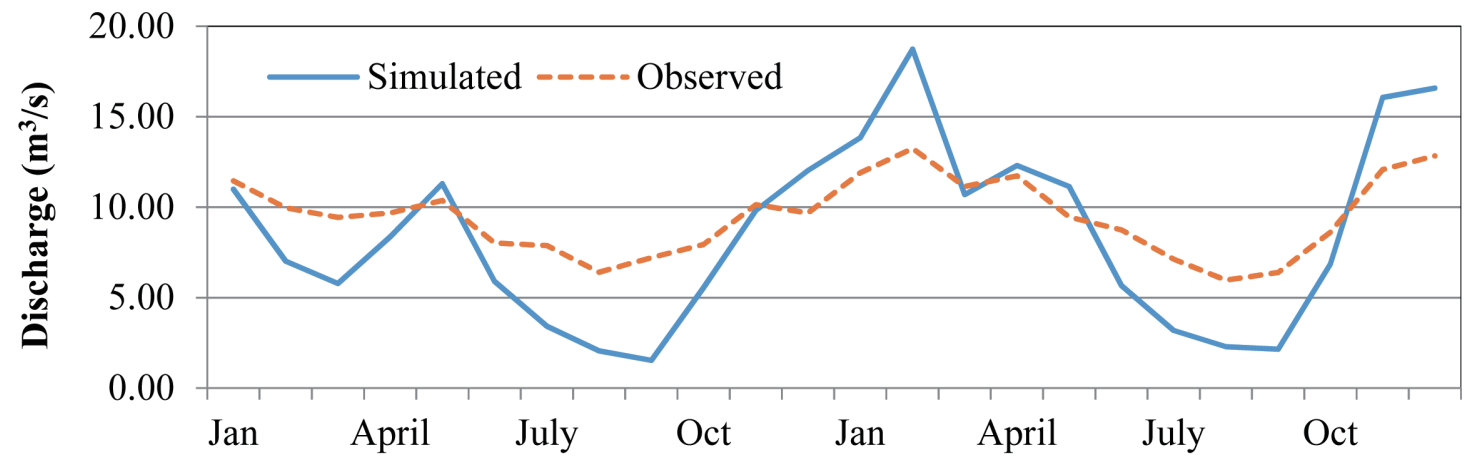

Time (month)

Fig. 10 Comparison of simulated NRECA method and observed monthly river discharge for the calibration period Jan-Dec 2011 and validation period Jan-Dec 2012.

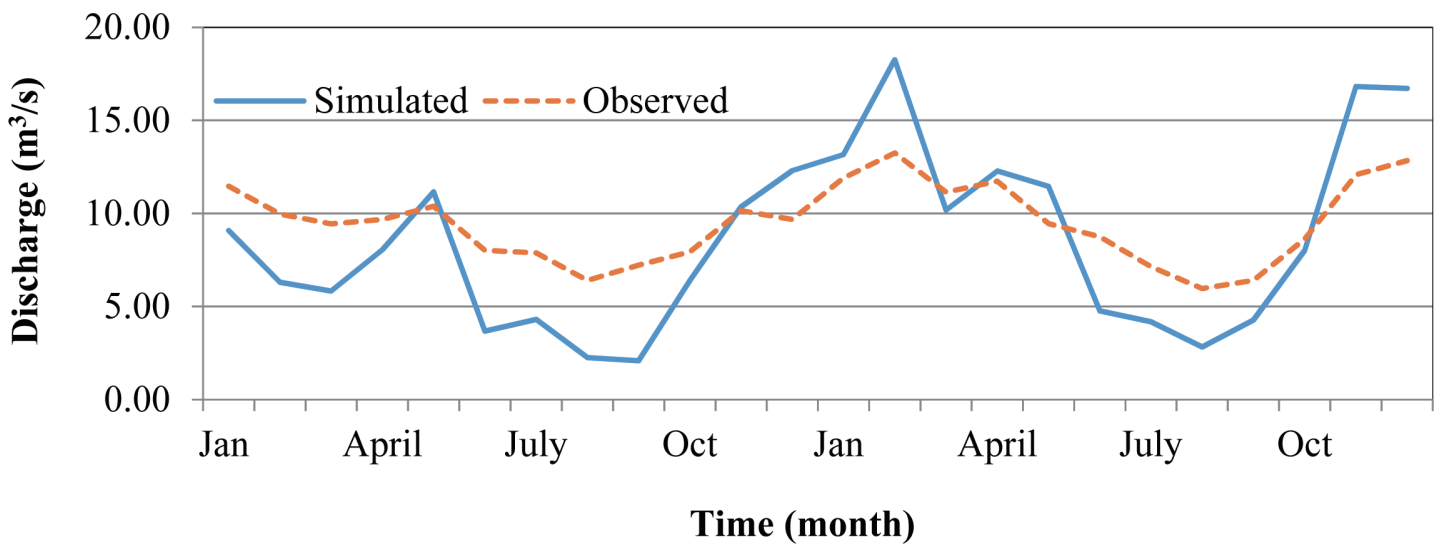

Fig. 11 Comparison of simulated FJ. Mock method and observed monthly river discharge for the calibration period Jan-Dec 2011 and validation period Jan-Dec 2012.

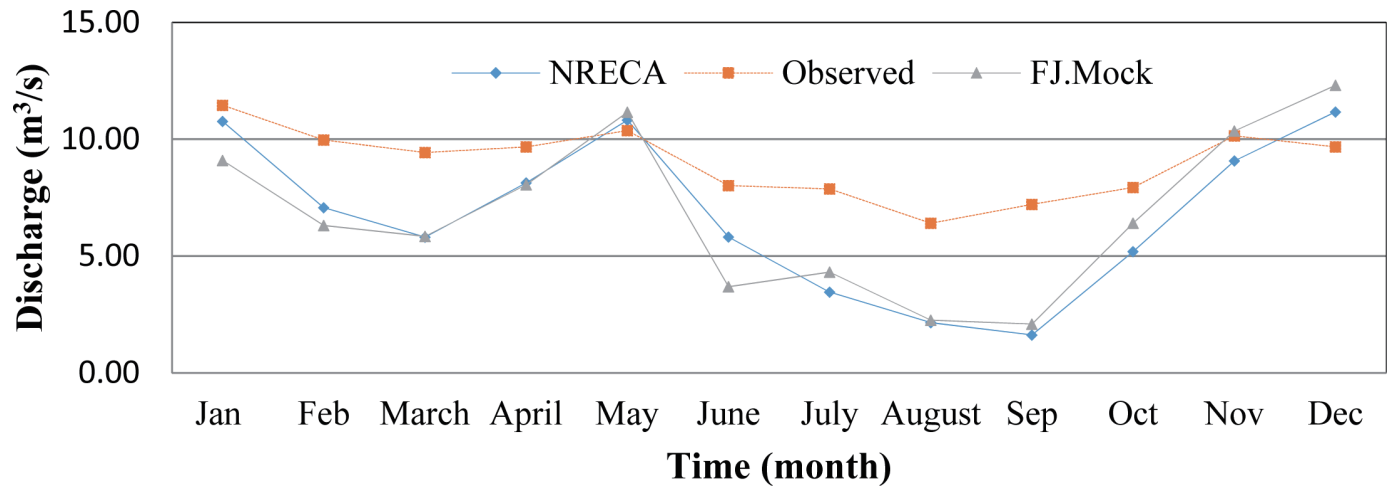

Fig. 12 Comparison between simulated and observed discharge in the UMC river basin. 
Table 7 Water availability in the UMC river basin.

\begin{tabular}{|c|c|c|c|c|c|c|c|c|c|c|c|c|}
\hline Year & Jan & Feb & March & Apr & May & Jun & Jul & Aug & Sept & Oct & Nov & Dec \\
\hline 2008 & 19.76 & 34.85 & 31.41 & 26.08 & 15.05 & 9.42 & 6.0 & 6.92 & 8.57 & 8.84 & 28.12 & 17.38 \\
\hline 2009 & 29.18 & 32.11 & 9.39 & 24.93 & 0 & 16.21 & 8.58 & 5.80 & 4.37 & 11.27 & 77 & 10.15 \\
\hline 2010 & 21.00 & 30.51 & 25.40 & 9.88 & 20.04 & 17.88 & 13.19 & 18.71 & 25.62 & 20.92 & 22.84 & 16.87 \\
\hline 2011 & 17.50 & 11.22 & 9.43 & 13.87 & 18.91 & 10.04 & 5.92 & 3.66 & 2.76 & 9.30 & 16.34 & 20.06 \\
\hline 2012 & 20.41 & 29.20 & 16.76 & 19.84 & 18.25 & 9.38 & 5.35 & 3.91 & 3.68 & 11.29 & 26.38 & 27.50 \\
\hline Average & 21.57 & 27.58 & 22.48 & 18.92 & 19.46 & 12.58 & 7.82 & 7.80 & 9.00 & 12.32 & 21.11 & 18.39 \\
\hline
\end{tabular}

Table 8 Water users in the UMC river basin year of 2014.

\begin{tabular}{lllc}
\hline \hline No. & \multicolumn{1}{c}{ Water use } & \multicolumn{1}{c}{ Unit } & Amount \\
\hline 1 & Population & million people & 3.79 \\
2 & Big industry & unit & 1,158 \\
3 & Small industry & unit & 4,416 \\
4 & Industry worker & people & 144,679 \\
5 & Irrigation area & ha & 1,199 \\
6 & Environmental & million people & 3.79 \\
\hline
\end{tabular}

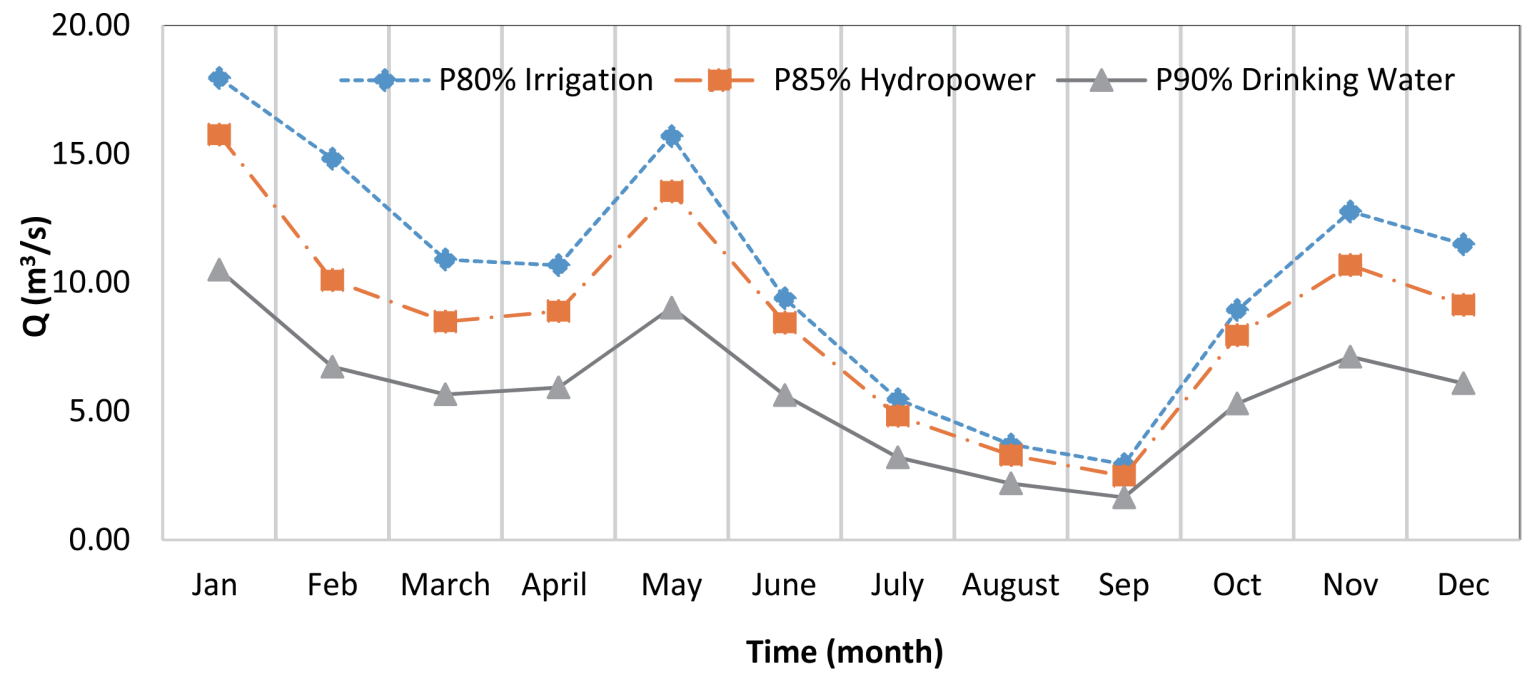

Fig. 13 Comparison of monthly dependable discharge in the UMC river basin.

Table 9 Existing number of residents of UMC river basin (million people).

\begin{tabular}{ccccccccccc}
\hline \hline Year \\
\hline 2005 & 2006 & 2007 & 2008 & 2009 & 2010 & 2011 & 2012 & 2013 & 2014 \\
2.82 & 3.07 & 3.15 & 3.21 & 3.13 & 3.15 & 3.20 & 3.59 & 3.65 & 3.79 \\
\hline
\end{tabular}

Table 10 Number of residents of UMC river basin (million people).

\begin{tabular}{lcccc}
\hline \hline Scenario & \multicolumn{3}{c}{ Year } \\
\cline { 2 - 5 } & 2014 & 2024 & 2034 & 2064 \\
\hline BAU & 3.79 & 5.26 & 7.31 & 19.59 \\
One & 3.79 & 6.17 & 10.06 & 43.46 \\
\hline
\end{tabular}


Table 11 Water demand projection based on BAU scenario.

\begin{tabular}{llrrrr}
\hline \hline \multirow{2}{*}{ No. } & Water Use & \multicolumn{4}{c}{ Water Demand $\left(10^{6} \mathrm{~m}^{3} /\right.$ year $)$} \\
\cline { 3 - 5 } & & 2014 & 2024 & 2034 & 2064 \\
\hline 1 & Domestic & 221.34 & 307.71 & 426.99 & $1,144.13$ \\
2 & Industrial & 32.25 & 44.80 & 62.22 & 166.73 \\
3 & Agriculture & 45.37 & 63.02 & 87.53 & 234.55 \\
4 & Environmental & 415.01 & 576.42 & 800.61 & $2,145.24$ \\
& Total & 713.97 & 991.66 & $1,377.36$ & $3,690.64$ \\
\hline
\end{tabular}

Table 12 Water demand projection based on scenario 1.

\begin{tabular}{llrrrr}
\hline \hline \multirow{2}{*}{ No. } & Water Use & \multicolumn{4}{c}{ Water Demand $\left(10^{6} \mathrm{~m}^{3}\right.$ year $)$} \\
\cline { 3 - 5 } & & 2014 & 2024 & \multicolumn{1}{c}{2034} & 2064 \\
\hline 1 & Domestic & 221.34 & 360.53 & 587.27 & $2,538.15$ \\
2 & Industrial & 32.25 & 52.54 & 85.58 & 369.87 \\
3 & Agriculture & 45.37 & 73.91 & 520.32 & $4,759.03$ \\
4 & Environmental & 415.01 & 676.00 & $1,101.13$ & $8,187.37$ \\
& Total & 713.97 & $1,162.98$ & $1,894.37$ & \\
\hline
\end{tabular}

Table 13 Volume of WS and WD for evaluation of different scenarios.

\begin{tabular}{|c|c|c|c|c|}
\hline \multirow[t]{2}{*}{ Year } & \multicolumn{2}{|c|}{ BAU } & \multirow{2}{*}{$\begin{array}{c}\text { Scenario } 1 \\
\text { Volume WD } \\
10^{6} \mathrm{~m}^{3}\end{array}$} & \multirow{2}{*}{$\begin{array}{c}\text { Scenario } 2 \\
\text { Volume WS } \\
10^{6} \mathrm{~m}^{3}\end{array}$} \\
\hline & $\begin{array}{c}\text { Volume WS } \\
10^{6} \mathrm{~m}^{3}\end{array}$ & $\begin{array}{c}\text { Volume WD } \\
10^{6} \mathrm{~m}^{3}\end{array}$ & & \\
\hline 2014 & 6276.42 & 713.97 & 713.97 & 5962.60 \\
\hline 2024 & 6276.42 & 991.66 & 1162.98 & 5962.60 \\
\hline 2034 & 6276.42 & 1377.36 & 1894.37 & 5962.60 \\
\hline 2064 & 6276.42 & 3690.64 & 8187.37 & 5962.60 \\
\hline
\end{tabular}

Table 14 IWSD values for evaluation of water supply demand capacity of different scenarios.

\begin{tabular}{ccccc}
\hline \hline IWSD & & & \\
Year & BAU & Scenario 1 & Scenario 2 & Mix scenario \\
\hline 2014 & 0.89 & 0.89 & 0.88 & 0.88 \\
2024 & 0.84 & 0.81 & 0.83 & 0.80 \\
2034 & 0.78 & 0.70 & 0.77 & 0.68 \\
2064 & 0.41 & -0.30 & 0.38 & -0.37 \\
\hline
\end{tabular}

supply demand capacity for each scenario can be seen in Table 14.

Based on IWSD analysis, the river can carry and support the economy, society, and environment from the year 2014 until the year 2064, as the IWSD values were all greater than zero for the BAU and scenario 2. In scenario 1 and the mix scenario, the $I W S D$ value is smaller than zero. The utilization of water resources for the planning year 2064 needs to consider other aspects such as recycling of water, water use efficiency, and search for new water sources.

\section{CONCLUSIONS}

Hydrological method was used to calculate the availability of water in a watershed based on the results of a comparison between simulated and measured discharge. In this study, we used the FJ. Mock and NRECA models because of the availability of data and the ease of calculation methods. Data included daily rainfall data, potential evapotranspiration data, and hydrologic watershed characteristics. The model accuracy was evaluated by calibration and validation between the simulation results and observation data using two 
indicators: the $r$ and the $V E$. The model used was the model that has the greatest $\mathrm{r}$ and the smallest $V E$.

The NRECA model gave an $r$ of 0.90 and $V E$ of 0.25 . The FJ. Mock model had an $r$ of 0.81 and $V E$ of 0.24 . Based on these calibrated results, the hydrological model used in this study was the NRECA model. This model can be used to calculate the water availability and analyze the dependable flow for multiple water needs (P90\% for drinking water, $\mathrm{P} 85 \%$ hydropower, and $\mathrm{P} 80 \%$ for irrigation).

Based on the $I W S D$, the river can carry and support the economy, society, and environment from the year 2014 until the year 2064, as the IWSD values were all greater than zero for BAU scenarios and scenario 2.

This hydrological method application can be used to evaluate the water supply demand capacity with the assumption value approach adapted to current conditions and future predictions for the water resources development plan along with the development strategy that needs to be done. Future research should further improve the accuracy of the results using more detailed data and refined assumptions. For example, time series data used for calculations and debit data for river measurements are more than or equal to 10 years.

\section{ACKNOWLEDGEMENTS}

This paper is supported by the data set of CiliwungCisadane River Basin Agency.

\section{REFERENCES}

[1] Alcamo J, Döll P, Henrichs T, Kaspar F, Lehner B, Rösch T, Siebert S: Global estimates of water withdrawals and availability under current and future “business-as-usual” conditions. Hydrol. Sci. J., 48(3), 339-348, 2003. doi:10.1623/hysj.48.3.339.45278

[2] Putra LA: Analysis of the Effectiveness of Ciawi Reservoir Using SWAT Model as an Effort of Flood Control of Ciliwung Watershed. Master thesis, Department of Civil and Environmental Engineering, Faculty of Agricultural Technology, IPB University, Bogor, Indonesia, 2015. [in Indonesian]
[3] Susanto A, Kerami D, Deliyanto B, Pramuhadi G: Analysis of the needs of reservoirs and reservoirs for flood control and sustainable water supply (case study of Upper Ciliwung River Basin). Research Report of Inter-University Cooperation, 424/Regional and City Planning, Regional and City Planning Studies Program, Faculty of Mathematics and Natural Sciences, Open University, Jakarta, Indonesia, 2013. [in Indonesian]

[4] Kesuma RP, Wahyudi AH, Suyanto: Application of mock method, NRECA, tank model, and rainrun in Trani Dam, Wonotoro, Sudangan, and Walikan. eJournal Civil Engineering Matrix, 1(4), 472-479, 2013. [in Indonesian]

[5] Crawford NH, Thurin SM: Hydrologic estimates for small hydroelectric projects: NRECA Small Decentralized Hydropower (SDH) Program. National Rural Electric Cooperative Association, Washington DC, USA, 1981.

[6] Mulya H, Hadirahardja J, Kodoatie R: Water resources management strategies on non-groundwater basin (non-cat) small islands (study case: Batam Island). Int. Ref. J. Eng. Sci., 2(7), 14-22, 2013.

[7] Sucaka B, Hadiani R, Wahyudi AH: Reliability analysis of mock method with rain data 5, 10, 15 daily and 1 monthly. e-Journal Civil Engineering Matrix, 1(4), 480-487, 2013. [in Indonesian]

[8] Ciliwung-Cisadane River Basin Agency: Pattern of Water Resources Management. Ciliwung-Cisadane River Basin Agency, Jakarta, Indonesia, pp. 1-195, 2014. [in Indonesian]

[9] European Commission: Technical Report-2015-090, Guidance Document on the Application of Water Balances for Supporting the Implementation of the WFD, Final - Version 6.1 - 18/05/2015, 2015. https://climateadapt.eea.europa.eu/metadata/guidances/guidancedocument-on-the-application-of-water-balances-forsupporting-the-implementation-of-the-wfd/11309477

[10] National Standardization Agency: SNI 7745-2012: The Procedure for Calculating Reference Plant Evapotranspiration with the Penman-Monteith Method. National Standardization Agency, Jakarta, Indonesia, 2012. [in Indonesian]

[11] Limantara LM: Reliability performance of Tambak Pocok small dam, Bangkalan of Indonesia. Asian J. Nat. Appl. Sci., 1(2), 5-14, 2012. 
[12] Shawul AA, Alamirew T, Dinka MO: Calibration and validation of SWAT model and estimation of water balance components of Shaya mountainous watershed, Southeastern Ethiopia. Hydrol. Earth Syst. Sci. Discuss., 10(11), 13955-13978, 2013. doi:10.5194/ hessd-10-13955-2013

[13] Komariah I: Study of Water Resources of Cipelang Watershed in order to Fulfill the Raw Water Requirement of Palasah International Airport Development Plan in Majalengka Regency. Master Theses, Faculty of Civil and Environmental Engineering, Bandung Institute of Technology, Bandung, Indonesia, 2006. [in Indonesian]

[14] Department of Public Works: Planning Criteria. Department of Public Works, Jakarta, Indonesia, 1996. [in Indonesian]

[15] Hendrata LA, Wuisan EM: Analysis of water availability of Talawaan River for irrigation needs in Talawaan Irrigation and Talawaan Irrigation Area. Tekno, 13(64), 48-55, 2015. [in Indonesian]

[16] Song X, Kong F, Zhan C: Assessment of water resources carrying capacity in Tianjin City of China. Water Resour. Manage., 25(3), 857-873, 2011. doi:10.1007/ s11269-010-9730-9
[17] Ciliwung-Cisadane River Basin Agency: Report: Water Alocation. Ciliwung-Cisadane River Basin Agency, Jakarta, Indonesia, pp. 1-50, 2013. [in Indonesian]

[18] Ouyang Y, Xu D, Leininger TD, Zand N: A system dynamic model to estimate hydrological process and water use in a eucalypt plantation. Ecol. Eng., 86(34), 290-299, 2016.

[19] Central Bureau of Statistics: Bogor Regency in Figures 2015. Bogor Regency, Bogor, Indonesia, pp. 1-311, 2015. [in Indonesian]

[20] Central Bureau of Statistics: Bogor City in Figures 2015. Bogor City, Bogor, Jawa Barat, Indonesia, pp. 1-209, 2015. [in Indonesian]

[21] Central Bureau of Statistics: Depok in Figures 2015. Depok Municipality, Depok, Jawa Barat, Indonesia, pp. 1-242, 2015. [in Indonesian]

[22] Shamseldin YS, Knight DW: River Basin Modeling for Flood Risk Mitigation. CRC Press Inc., Boca Raton, USA, 2005. 